\title{
Pengaruh Tipologi Profesi Warga Terhadap Pengembangan Kegiatan Kemasyarakatan Kampung Biru Arema
}

\author{
Najmah Zahiroh ${ }^{*}$, Nuraini Lailiya Hanum², Okta Pujiana3 ${ }^{3}$, Sakshita Jihan ${ }^{4}$, Saiful Rofik \\ Rosikin $^{5}$
}

${ }_{1}^{1}$ Program Studi Sosiologi Fakultas Ilmu Sosial Universitas Negeri Malang, Malang, Indonesia ${ }^{2}$ Program Studi Sosiologi Fakultas Ilmu Sosial Universitas Negeri Malang, Malang, Indonesia ${ }^{3}$ Program Studi Sosiologi Fakultas Ilmu Sosial Universitas Negeri Malang, Malang, Indonesia ${ }^{4}$ Program Studi Sosiologi Fakultas Ilmu Sosial Universitas Negeri Malang, Malang, Indonesia ${ }^{5}$ Program Studi Sosiologi Fakultas Ilmu Sosial Universitas Negeri Malang, Malang, Indonesia

\section{A R T I C L E I N F O}

Received 15 Mei 2018

Accepted 28 Juni 2018

Available online 30 Juni 2018

\section{Kata Kunci:}

Tipologi; Profesi Destinasi

Wisata; Solidaritas Mekanis

Keywords:

Typology; Profession;

Tourism Destination;

Mechanical Solidarity

\begin{abstract}
A B S T R A K
Kampung Biru Arema Malang adalah salah satu dari destinasi wisata baru yang ada di Kota Malang, destinasi wisata ini memberikan pemandangan dan panorama yang indah dari sudut kota. Di samping itu, beragamnya permasalahan sosial yang ada di desa wisata ini menjadi menarik untuk dikaji. Terlebih, karena tipologi profesi warga Kampung Biru Arema dalam memajukan desanya. Penelitian ini menggunakan metode kuantitatif. Penelitian ini memaparkan harmonisasi dari solidaritas mekanis yang berbasis moralitas antara individu dan individu dengan kelompok.

A B S T R A C T

Kampung Biru Arema Malang is one of the new tourism destinations that bring a beauty panoramic view from the corner of the city. Various social problems can be studied from this education village. Researchers choose Kampung Biru Arema as the object of the research because the profession typology $p$ that settled in there is quite diverse and interesting to be studied, this research used quantitative method. The research suggests that harmonization is meant by the mechanical solidarity based on morality consciousness between individuals and individuals with the groups.
\end{abstract}

\section{Pendahuluan}

Pemerintah Kota (Pemkot) Malang telah mengusung kampung wisata tematik baru yang bernuansa biru sebagai lambang klub sepakbola Arema. Kampung wisata ini telah selesai proses pembangunannya pada akhir tahun 2017 lalu. Kepala Badan Perencanaan, Penelitian dan Pengembangan (Barenlitbang) Pemkot Malang, Erik Setyo Santoso menerangkan, terdapat 500 rumah yang dicat warna biru.

Ratusan rumah tersebut merupakan gabungan dari RW 04 dan 05 Kelurahan Kidul Dalem, Klojen, Kota Malang, Jawa Timur (Jatim). Area ini berbatasan langsung dengan Kampung Warnawarni dan Tridi. Kampung Biru Arema tersebut merupakan kelanjutan program penataan kawasan dari pemkot Malang.

\footnotetext{
Corresponding author.

E-mail addresses: penulis1@undiksha.ac.id (Penulis Pertama),penulis2@undiksha.ac.id (Penulis Kedua)
} 
Keberadaan kampung ini semakin melengkapi wisata kampung tematik atau kampung karakter di Kota Malang. Kawasan tersebut bersebrangan dengan Kampung Tridi (Kelurahan Ksatrian) dan Kampung Warna-Warni (Kelurahan Jodipan). Ketiga kawasan tersebut semula dikenal kumuh dan kotor, namun saat ini berubah menjadi indah dengan corak warna-warni rumah.

Kerja sama yang terjalin antar warga terlepas dari perbedaan dan tipografi pekerjaan ini tadi juga bisa menjadi cerminan dari solidaritas mekanis. Yaitu masyarakat yang ditandai oleh solidaritas mekanis menjadi satu dan padu karena selutuh orang adalah generalis. Ikatan dalam masyarakat seperti ini terjadi karena mereka terlibat dalam aktivitas yang sama dan memiliki tanggung jawab yang sama (Durkheim, dalam Ritzer:2008).

\section{Metode}

Penelitian yang berjudul Pengaruh Tipologi Profesi Warga Terhadap Pengembangan Potensi Wisata Kampung Biru Arema RW 5 dan RW 4 Kelurahan Kidul Daleem Kecamatan Klojen Kota Malang Jawa Timur ini menggunakan metode penelitian Kuantitatif. Penelitian kuantitatif merupakan penelitian berparadigma positifis dengan bentuk data yang didapat dan yang dihasilkan berupa atau berkaitan dengan angka-angka. Rancangan penelitian ini berupa pengumpulan data warga, yang dilanjutkan dengan penyebaran angket kuesioner pada warga yang menjadi sampel dalam penelitian ini.

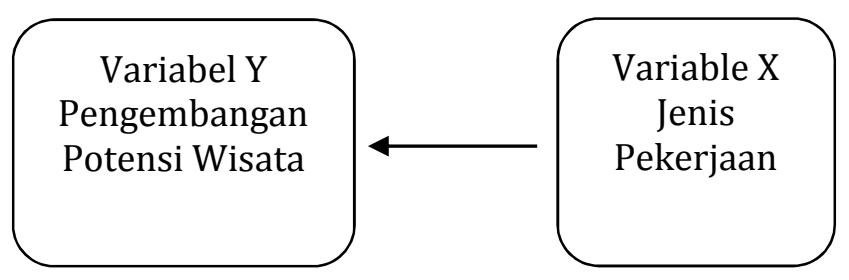

Variable dalam penelitian ini terdiri dari dua variable, yaitu variable dependen (Y) dan variable bebas (X). Variable dependen berupa Pengembangan Potensi Wisata, sedangkan variable bebas berupa jenis pekerjaan. Variable ini terpecah menjadi beberapa indicator. Indicator ini yaitu Jenis pekerjaan, Usia, Intensitas lama mengabdi dalam pekerjaan, jenis kelamin, Kontribusi masyarakat dalam kegiatan kemasyarakatan, Kontribusi masyarakat terhadap program pemerintah, dan kontribusi masyarakat terhadap program unit kegiatan.

Populasi yang akan digunakan adalah keseluruhan penduduk yang terdapat Kampung Biru Arema. Keseluruhan penduduk Kampung Biru Arema berjumlah 1541 penduduk yang nantinya akan diambil 10\% dari keseluruhan jumlah penduduk yakni sejumlah 154 orang yang kemudian akan dijadikan sampel penelitian. Populasi adalah keseluruhan penduduk Kampung Biru Arema yaitu berjumlah 1541 penduduk. Sampel adalah 10\% dari keseluruhan jumlah penduduk. Kampung Biru Arema Yaitu 1541penduduk maka dapat diambil 154 sebagai sampel.

Pengambilan sampel menggunakan metode Simple Random Sampling dengan teknik Systematic Sampling.Pengambilan sampel ini menggunakan populasi yang homogen sehingga keseluruhan dari populasi yang telah ditentukan mendapatkan kesempatan yang sama untuk menjadi sample penelitian. (Arikunto dalam Golu 2002). Systematic Samplingharus dipilih secara acak, sedangkan unsur-unsur selanjutnya dipilih secara sistematis menurut suatu pola tertentu. (Masri 2006).

\section{Hasil dan pembahasan}

Hasil Berdasarkan data pekerjaan warga dengan latar belakang yang berbeda-beda akan memberikan kontribusi yang berbeda terhadap pengembangan kegiatan masyarakat kampung biru. Pengaruh jenis pekerjaan terhadap pengembangan kegiatan masyarakat di Kampung Biru Arema ini yang akan dikaji. Masyarakat kampung biru memiliki kegiatan masyarakat berupa karja bakti yang dilaksanakan selama sebulan sekali yang diikuti oleh seluruh warga. 
Kegiatan ini bertujuan memupuk solidaritas yang terjalin antarwarga serta menjadikan Kampung Biru lebih indah dan bersih. Kegiatan kerja bakti ini bersifat wajib dan suka rela. Kerja sama yang terjalin antar warga terlepas dari peerbedaan dan tipografi pekerjaan ini juga bisa menjadi cerminan dari solidaritas mekanis. Yaitu masyarakat yang ditandai oleh solidaritas mekanis menjadi satu padu karena seluruh orang adalah generalis. Ikatan dalam masyarakat seperti ini terjadi karena mereka terlibat dalam aktivitas yang sama dan memiliki tanggung jawab sama (Durkheim, dalam Ritzer: 2008).

Lebih lanjutnya, menurut Durkheim di dalam masyarakat yang dibentuk oleh solidaritas mekanis, kesadaran koletif pun melingkupi seluruh masyarakat dan anggotanya yang isinya juga ada unsur-unsur religius. Dari penjabaran diatas, maka peneliti mengambil rumusan masalah meliputi bagaimana pengaruh jenis pekerjaan terhadap pengembangan kegiatan kemasyarakatan di kampung biru dan bagaimana kontribusi masyarakat dalam mengembangkan kegiatan kemasyarakatan di kampung biru.

Hipotesis yang diajukan antara lain :

1. H0: Lama bekerja tidak mempengaruhi pengembangan kegiatan kemasyarakatan di Kampung Biru Arema.

H1: Lama bekerja mempengaruhi pengembangan kegiatankemasyarakatan di Kampung Biru Arema.

2. H0: Jam kerja tidak mempengaruhi kontribusi pengembangan kegiatan kemasyarakatan Kampung Biru Arema.

H1: Jam kerja mempengaruhi kontribusi pengembangan kegiatan kemasyarakatan Kampung Biru Arema..

3. H0: Jenis pekerjaan tidak mempengaruhi kontribusi masyarakat dalam pengembangan kegiatan kemasyarakatan.

H1: Jenis pekerjaan mempengaruhi kontribusi masyarakat dalam pengembangan kegiatan kemasyarakatan.

4. H0: Jenis pekerjaan tidak mempengaruhi kontribusi masyarakat dalam pengembangan kegiatan kemasyarakatan Kampung Biru Arema.

H1: Jenis pekerjaan mempengaruhi kontribusi masyarakat dalam pengembangan kegiatan kemasyarakatan Kampung Biru Arema.

Perolehan data dalam penyebaran kuesioner pada poin-poin pendukung dalam hipotesis pertama yakni dalam pertanyaan yang menjadi bagian dari hipotesis pertama yakni diperoleh data responden berjenis pekerjaan mayoritas tidak bekerja dengan prosenstase sejumlah $35.7 \%$ atau sejumlah 55 orang. $26.6 \%$ berpekerjaan sebagai karyawan atau seumlah 41 orang. $21.4 \%$ berpekerjaan sebagai wiraswasta atau sejumlah 33 orang. Dan $16.2 \%$ berpekerjaan sebagai buruh atau sejumlah 25 orang. Data tersebut dapat dilihat dalam tabel dibawah ini.

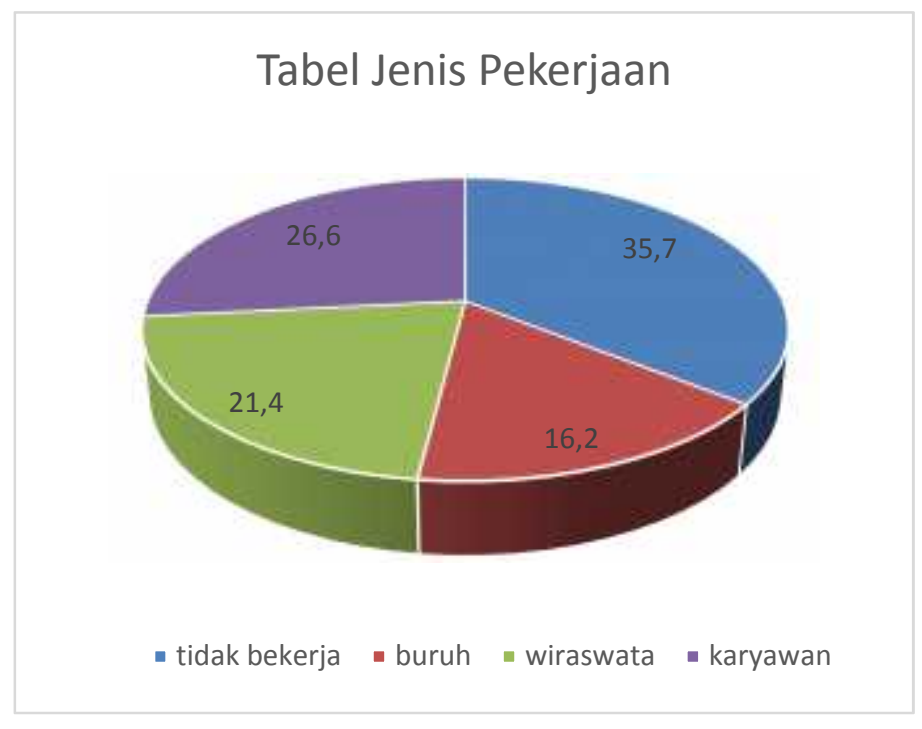


Kemudian didapati pula penggolongan responden berdasarkan lama bekerja. Terdapat 46.8\% warga sudah lebih dari 6 tahun menggeluti pekerjaannya. $37.7 \%$ warga 4 tahun lebih 1 hari sampai 6 tahun menggeluti pekerjaannya. 13\% warga 2 tahun lebih 1 hari sampai 4 tahun menggeluti pekerjaanya. Dan 2.6\% warga kurang dari 2 tahun menggeluti pekerjaannya. Hal ini disebabkan oleh banyaknya warga pindahan, bukan asli penduduk Kampung Biru Arema namun telah menetap di Kampung Biru Arema hingga memiliki Kartu Keluarga yang telah resmi menerangkan bahwa warga terkait telah menjadi warga resmi Kampung Biru Arema meskipun bukan warga asli dari Kampung Biru Arema itu sendiri.

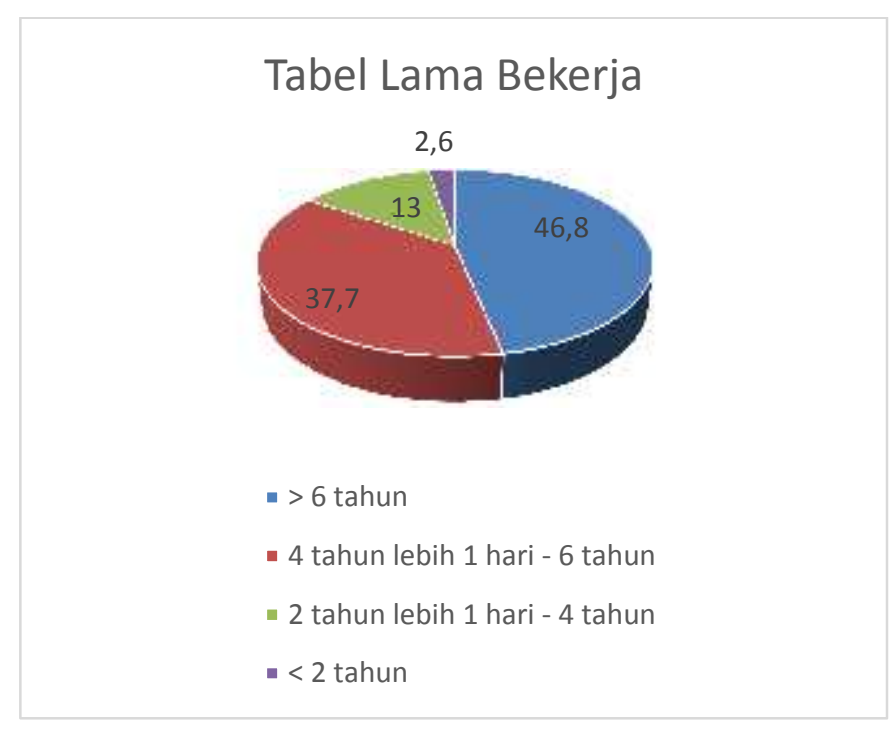

Kemudian didapati penggolongan jam kerja responden Kampung Biru Arema dalam kurun waktu satu miggu. Dalam satu minggu terdapat $42.9 \%$ responden yang bekerja selama 30 jam lebih 1 menit sampai 50 jam. 41.6\% responden yang bekera selama lebih dari 50 jam. 14.9\% responden yang bekerja selama 10 jam lebih 1 menit sampai 30 jam. $0.6 \%$ responden yang bekerja kurang dari 10 jam. Penggolongan tersebut tertera dalam tabel dibawah ini.

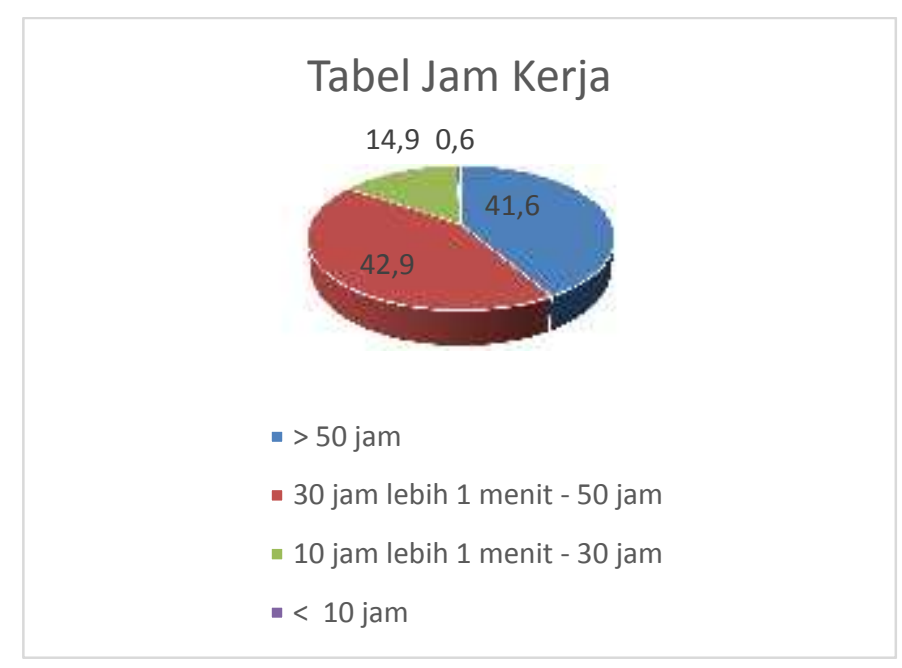

Kemudian keikutsertaan masyarakat dalam kegiatan kerjabakti, diperoleh data bahwa masyarakat setempat cenderung aktif dalam kegiatan tersebut dibuktikan dengan sejumlah 44.8\% warga ikut dalam kegiatan kerjabakti 2 kali dalam 1 bulan. 35.1\% ikut kerjabakti 3 kali dalam 1 bulan. 16.2\% tidak pernah ikut kerjabakti. Dan 3.9\% warga ikut kerjabakti 1 kali dalam 1 bulan. Data tersebut tertera dalam diagram dibawah ini. 


\section{Tabel Kegiatan Kerjabakti}

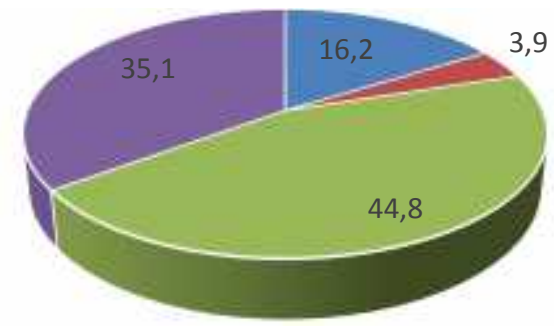

- tidak pernah 1 kali dalam 1 bulan

- 2 kali dalam 1 bulan - 3 kali dalam 1 bulan

Berdasarkan pengakuan warga setempat, kegiatan kerjabakti dilakukan dalam jangka waktu dua sampai tiga minggu sekali. Sehingga terkadang warga tidak dapat menikuti kegiatan tersebut karena berbenturan dengan kegiatan yang lain dan tentunya dianggap lebih penting bagi individu yang berkaitan tersebut.

Kemudian keikutsertaan warga dalam kegiatan kerajinan tangan warga juga cukup aktif. Dibuktikan dengan sejumlah $37.7 \%$ warga mengikuti kegiatan kerajinan tagan 3 kali dalam 1 bulan. $32.5 \%$ warga tidak pernah mengikuti kegiatan $22.7 \%$ warga ikut kegiatan 2 kali dalam 1 bulan. $7.1 \%$ warga ikut kegiatan 1 kali dalam 1 bulan. Data tersebut tertera dalam tabel dibawah ini.

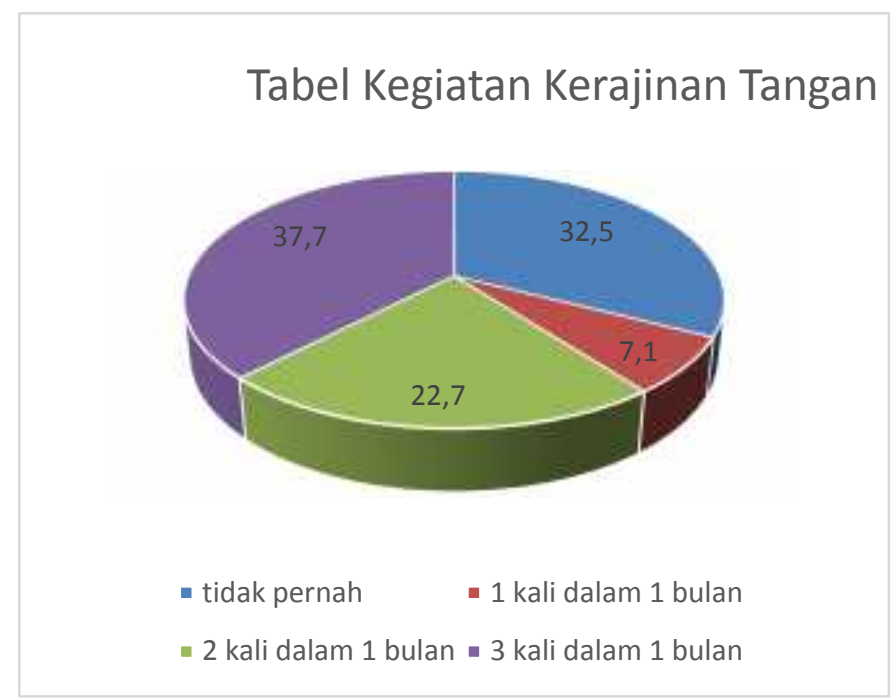

Warga yang mengikutikegiatan kerjainan tangan kebanyakan adalah perempuan. Karena dalam rangka mengisi waktu luang dan untuk menjalin kedekatan dengan masyarakat sekitar. Hanya sebagian saja warga yan mengikuti kegiatan kerjainan tangan berjenis kelamin laki-laki. Karena kegiatan tersebut dilakuakan saat jam-jam efektif bekerja. Sehingga jarang laki-laki mengikuti kegiatan tersebut.

Kemudian dalam kegiatan koperasi simpan pinjam masyarakat setempat cukup aktif. Dibuktikan dengan sejumlah $66.2 \%$ warga mengikuti kegiatan tersebut 1 kali dalam 1 bulan. 18.8\% warga tidak pernah ikut. Dan $14.9 \%$ warga ikut 2 kali dalam 1 bulan. Hal tersebut terjadi karena warga menggunakan koperasi sismpan pinjam tersebut untuk modal kerja. 


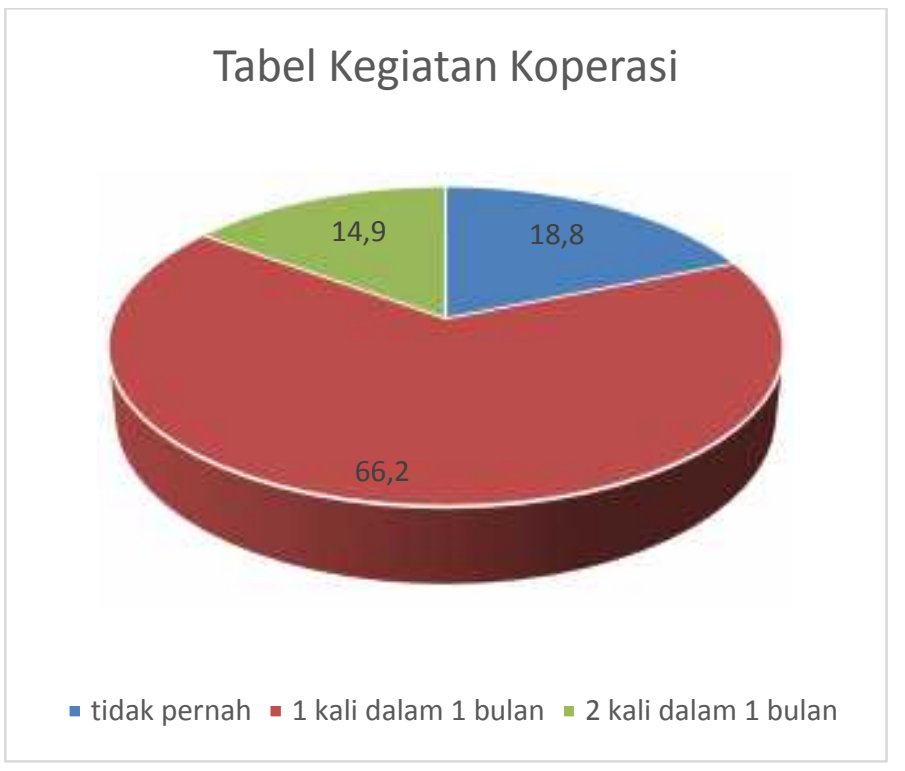

Kemudian keikutsertaan masyarakat dalam kegiatan pengajian tergolong sangat aktif. Terbukti dengan sejumlah 53.9\% masyarakat ikut kegiatan 3 kali dalam 1 bulan. 31.8\% masyarakat ikut kegiatan 2 kali dalam 1 bulan. 7.8\% tidak pernah mengikuti kegiatan. Dan 6.5\% warga ikut kerjabakti dalam 1 kali dalam 1 bulan. Keikutsertaan warga dikarenakan tiap satu minggu sekali pasti diadakan kegiatan Dziba'an bagi kaum perempuan. Kemudian Tahlilan bagi kaum laki-laki. Keikutsertaan warga didorong oleh kesadaran warga akan kewajiban beribadah dan pentingnya membangun kedekatan dengan masyarakat setempat. Kegiatan tersebut biasnya diadakan pada hari Jum'at untuk Tahlilan. Sehingga kegiatan keagamaan di Kampung Biru Arema sangatlah berjalan aktif dengan dorongan kesadaan dari masyarakat setempat itu sendiri.

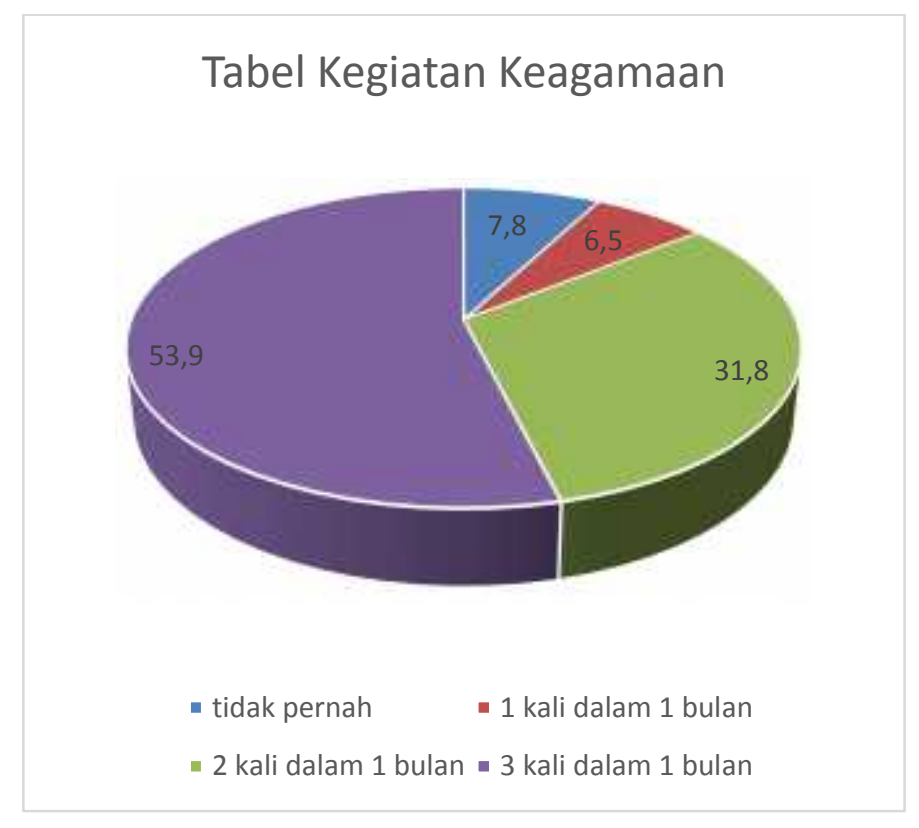

Kemudian keikutsertaan masyarakat dalam kegiatan PKK cukup aktif. Karena sejumlah 65.6\% warga mengikuti kegiatan PKK 1 kali dalam 1 bulan. 22.1\% warga ikut 2 kali dalam 1 bulan. 9.1\% warga ikut 2 kali dalam 1 bulan. 3.2\% warga ikut 3 kali dalam 1 bulan. Dan 9.1\% warga tidak pernah ikut. Hal tersebut terjadi karena banyaknya kegiatan yang diadakan oleh PKK itu sendiri. Seperti ajang perlombaan masak dan lain sebagainya. 


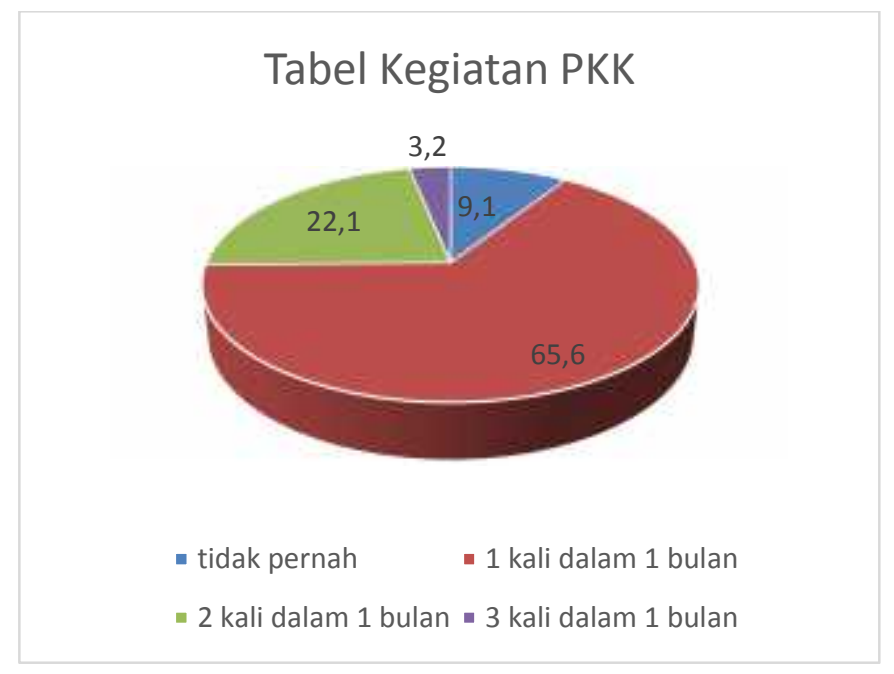

Kemudian keikutsertaan masyarakat dalam kegiatan posyyandu cenderung aktif. Dibuktikan dengan sejumlah $57.8 \%$ masyarakat ikut kegiatan 1 kali dalam 1 bulan. $1.9 \%$ ikut 2 kali dalam 1 bulan. 40.3\% tidak pernah mengikuti. Hal tersebut terjadi karena masyarakat setempat sangatlah perduli dengan kesehatan anaknya. Para lansia pun ikut serta dalam menjaga kesehatan tubuhnya.

Kemudian responden juga tentu memiliki kedudukan dalam suatu kegiatan masyarakat yang tengah diselenggarakan. Sejumlah $29.9 \%$ responden menjadi panitia dalam kegiatan kemasyarakatan. $29.9 \%$ responden menjadi partisipan kegiatan kemasyarakatan. 26\% responden sebagai pengurus harian kegitan. $14.3 \%$ responden menjadi anggota pasif dalam kegiatan kemasyarakatan. Pengurus harian memanglah sangat sedikit karena memang pada dasarnya pengurus harian hanya berisi orang-orang tertentu saja, karena dalam suatu kegiatan pasti lebih banyak anggota yang menjadi partisipan saja.

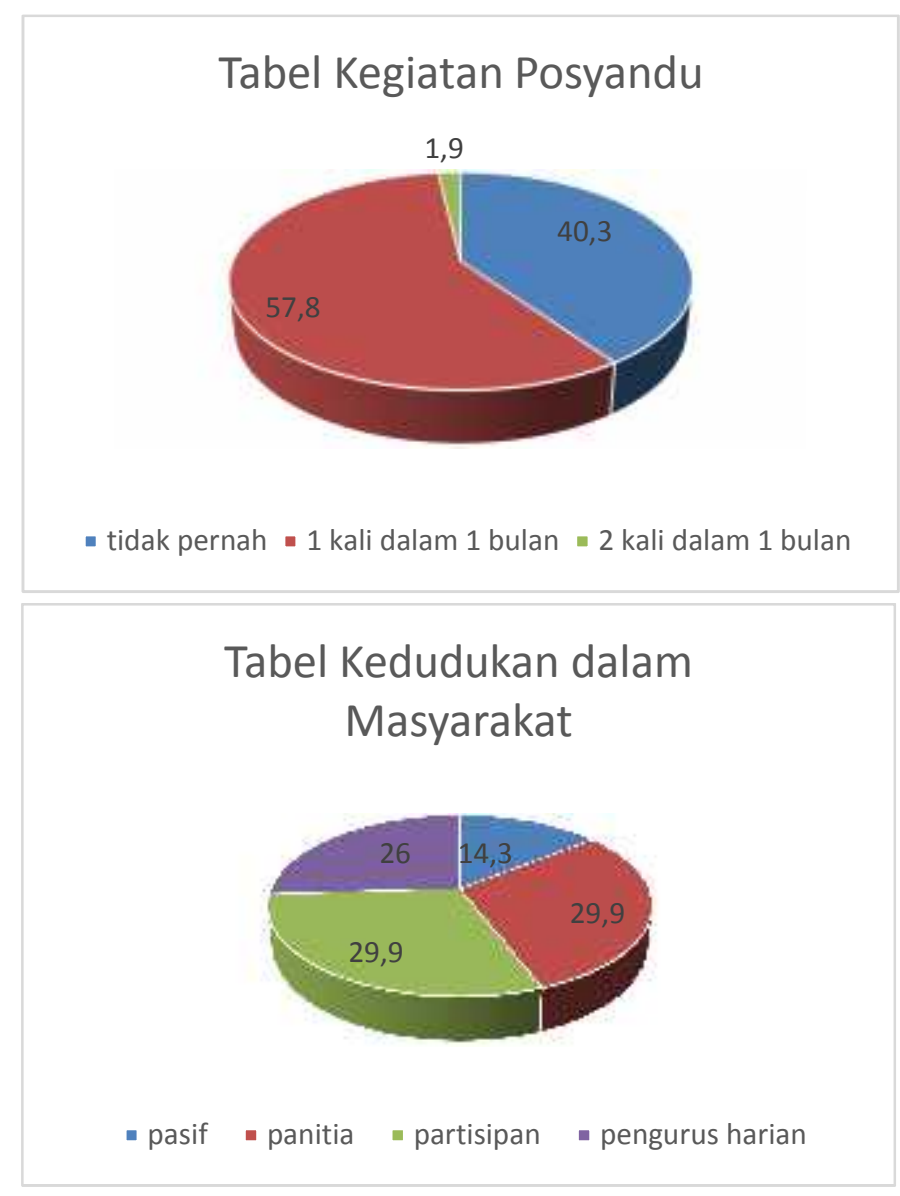


Kemudian dalam dukungan kegiatan masyarakat, sejumlah $30.5 \%$ responden yang memberikan dukungan untuk kegiatan kemasyarakatan untuk meningkatkan dan mengembangkan potensi dan kualitas SDM. Sejumlah 31.2\% tidak memberikan dukungan untuk pengembangan kegiatan karena merasa tidak berpengaruh bagi dirinya sendiri. 20.1\% memberikan dukungan karena untuk mengisi waktu luangnya. $18.2 \%$ tidak mendukung karena merasa masih banyak kegiatan yang dianggap lebih penting. Seperti tertera dalam diagram dibawah ini.

\section{Dana Pengembangan Kegiatan}

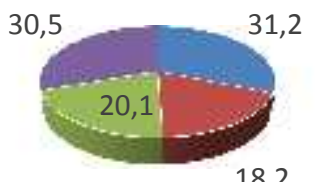

18,2

- Tidak, karena ada atau tidaknya kegiatan tersebut tidak berpengaruh bagi saya

- Tidak, karena buang waktu dan masih ada banyak pekerjaan lain yang harus dikerjakaan

- Ya, karena untuk mengisi waktu luang

- Ya, karena untuk mengembangkan potensi dan kualitas SDM

Kemudian ketika dalam sumbangsih dana responden cenderung aktif. Dibuktikan dengan sejumlah 64,3\% warga memberikan dana apabila bersifat wajib. 9.7\% memberikan dana apabila ada uang lebih. $21.4 \%$ responden enggan memberikan dana karena merasa tidak diuntungkan dengan kegiatan kemsyarakatan. Dan $4.5 \%$ warga enggan memberikan dana karena beranggapan bahwa masih banyak pengeluaran lain yang lebih penting. Seperti tercermin dalam tabel dibawah ini.

\section{Dana Pengembangan Kegiatan}

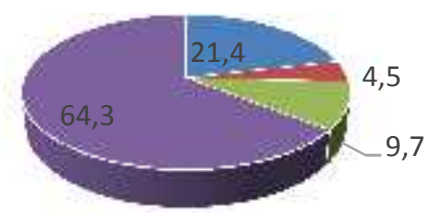

$$
\begin{aligned}
& \text { - Tidak, karena tidak menguntungkan bagi saya } \\
& \text { - Tidak, karena banyak pengeluaran pribadi } \\
& \text { - Ya, apabila ada uang lebih } \\
& \text { - Ya, apabila ada iuran wajib }
\end{aligned}
$$

Berdasarkan data yang diperoleh diatas, dilakukan analisis data menggunakan aplikasi SPSS dengan jumlah sampel 154 tanpa ada missing data yakni 0\%. Menunjukkan hasil bahwa jenis pekerjaan dengan kegiatan kerjabakti asymp.Sig sejumlah 0.169 , jenis pekerjaan dengan kegiatan koprasi simpan pinjam sejumlah 0.019 , jenis pekerjaan dengan kegiatan pengajian sejumlah 0.023, jenis pekerjaan dengan kegiatan PKK sejumlah 0.740, jenis pekerjaan dengan kegiatan posyandu sejumlah 0.667 dan jenis pekerjaan dengan kegiatan kerajinan tangan asymp.Sig sejumlah 0.003. darisini dapat disimpulkan bahwa Hipotesis pertama yang diterima adalah H0 karena mayoritas dari ke enam kegiatan adalah Asiymp.Sig diatas 0.05. yakni 0.169, 
$0.019,0.023,0.740$ dan 0,667 . H0 berbunyi jenis pekerjaan tidak mempengaruhi pengembangan kegiatan kemasyarakatan Kampung Biru Arema.

Untuk menguji hipotesis kedua juga dilakukan dengan cara yang sama seperti pengujian hipotesis pertama yang menghasilkan data sebagai berikut: lama bekerja dengan kerja bakti Asiymp.Sig sejumlah 0.000, lama bekerja dengan posyandu sejumlah Asiymp.Sig 0.000, lama bekerja dengan kegiatan kerajinan tangan Asiymp.Sig sejumlah 0.101, lama bekerja dengan kegiatan koprasi Asiymp.Sig sejumlah 0.049, lama bekerja dengan kegiatan pengajian Asymp.Sig sejumlah 0.094 dan lama bekerja dengan kegiatan PKK Asymp.Sig sejumlah 0.048. dari keenam opsi kegiatan terdapat empat Asymp.Sig yang jumlahnya diatas 0.05 yakni 0.101, 0.049, 0.094 dan 0.048. Sehingga dapat ditarik kesimpulan bahwa HO diterima, karena mayoritas dari jumlah keempat Asiymp.Sig tersebut nilainya berada diatas 0.05. sedangkan H0 dalam hipotesis kedua berbunyi lama bekerja tidak mempengaruhi pengembangan kegiatan kemasyarakatan di Kampung Biru Arema.

Untuk menguji hipotesis ketiga dilakukan dengan cara yang sama sebagaimana cara sebelumnya. Pengujian jam kera dengan kegiatan kerjabakti Asymp.Sig sejumlah 0.286, pengujian jam kerja dengan kegiatan Asymp.Sig sejumlaah 0.013, jam kerja dengan kegiatan PKK Asymp.Sig sejumlah 0.149, jam kerja dengan kegiatan posyandu Asymp.Sig sejumlah 0.551, jam kerja dengan kegiatan kerajinan tangan Asymp.Sig sejumlah 0.005 dan jam kerja dengan kegiatan koperasi simpan pinjam Asymp.Sig sejumlah 0.000. keenap opsi kegiatan yang berjalan dalam Kampung Biru Arema sejumlah 4 opsi yang memiliki nilai diatas 0.05, sehingga dapat disimpulkan bahwa HO diterima. HO berbunyi jam kerja tidak mempengaruhi pengembangan kegiatan kemasyarakat di Kampung Biru Arema.

Untuk menguji hipotesis keempat dilakukan dengan cara sama sebagaimana sebelumnya. Penguian jenis pekerjaan dengan kedudukan dalam kegiatan kemasyarakatan Asymp.Sig sejumlah 0.240, jenispekerjaan dengan dukungan masyarakat terhadap kegiatan kemasyarakatan Asymp.Sig sejumlah 0.001 dan jenis pekerjaan dengan pemberian dana dari masyarakat untuk pengembangan kegiatan kemasyarakatan Asymp.Sig sejumlah 0.009. dari ketiga opsi pertanyaan yang berhubungan dengan hipotesis keempat menunjukkan dua pertanyaan yang memiliki Asymp.Sig dibawah 0.05 yakni 0.001 dan 0.009 . sehingga menunjukkan bahwa $\mathrm{H} 1$ diterima karena mayoritas Asymp.Sig dibawah 0.05. dapat disimpulkan hipotesis keempat yang diterima adalah $\mathrm{H} 1$ yang berbunyi jenis pekerjaan mempengaruhi kontribusi masyarakat dalam pengembangan kegiatan kemasyarakatan di Kampung Biru Arema.

Peneliti melakukan observasi di lapangan dengan menyebarkan angket. Populasi yang akan digunakan adalah keseluruhan penduduk yang terdapat Kampung Biru Arema. Keseluruhan penduduk Kampung Biru Arema berjumlah 1541 penduduk yang nantinya akan diambil $10 \%$ dari keseluruhan jumlah penduduk yakni sejumlah 154 orang yang kemudian akan dijadikan sampel penelitian. Pengambilan sampel menggunakan metode Simple Random Sampling dengan teknik Systematic Sampling. Dari data yang kami peroleh, pekerjaan yang ditekuni oleh warga berbeda-beda, yakni wirausaha, karyawan, buruh, dll. Hal ini juga mempengaruhi kontribusi mereka dalam mengikuti kegiatan di kampung biru contohnya kerja bakti. Hasil temuan kami di lapangan yaitu kebanyakan warga yang berprofesi sebagai karyawan, hanya mengikuti 2-3 kali kerja bakti saja dalam satu bulan. Kegiatan kerja bakti dilaksanakan setiap minggu artinya ada 4 kali kegiatan kerja bakti salam setiap bulan. Hal ini dilakukan untuk terus memperindah kampung biru oleh warga setempat agar semakin nyaman di datangi wisatawan.

Dari hasil wawancara kami, alasan mereka yang berprofesi sebagai karyawan tidak mengikuti kerja bakti karena banyaknya pekerjaan kantor yang harus dikerjakan, kurangnya waktu untuk istirahat oleh karena itu mereka memanfaatkan waktu luang untuk beristirahat dari segala pekerjaan. Oleh karena itu, kontribusi mereka yang bekerja sebagai karyawan tidak maksimal dibanding mereka yang bekerja sebagai wirausaha ataupun buruh. Tetapi warga yang kontribusinya kurang maksimal, mereka menggantinya dengan cara memberikan bantuan konsumsi untuk warga yang mengikuti kerja bakti. Bantuan konsumsi yang dimaksud yaitu 2 bungkus nasi untuk setiap satu keluarga yang tidak mengirimkan perwakilannya untuk kerja bakti. 


\section{Simpulan dan saran}

Berisi Berdasarkan dari pemaparan peneliti mengenai pengaruh tipologi profesi warga terhadap pengembangan kegiatan kemasyarakatan kampung Biru Arema, maka kita dapat melihat dan mengamati bahwa adanya solidaritas mekanis seperti yang dikatakan Durkheim dalam tulisan-tulisannya dapat kita jumpai di Kampung Biru Arema yang digadang-gadangkan sebagai desa wisata edukasi di Kota Malang, Jawa Timur.

Untuk membuktikan teori dan hipotesis yang berkesinambungan, maka dilakukan penelitian berbasis metode kuantitatif untuk menarik sampel dan pengolahan data secara sistematis dan ilmiah.

Tentu hal-hal yang dimaksud dalam penelitian tadi berkaitan dengan pengaruh jenis pekerjaan terhadap pengembangan kegiatan kemasyarakatan di Kampung Biru Arema itu sendiri. Dan menunjukkan bahwa berdasarkan data pekerjaan warga dengan latar belakang yang berbeda-beda memberikan kontribusi yang berbeda terhadap pengembangan kegiatan masyarakat Kampung Biru.

Dari jenis pekerjaan yang berbeda tadi membentuk sebuah tiografi warga dalam sumbangsinya membangun desa. Adanya kontribusi utama warga ialah Usaha Kecil Menengah (UKM) dan kerja bakti yang dilaksanakan setiap seminggu sekali.

Berdasarkan data pekerjaan warga dengan latar belakang yang berbeda-beda memberikan kontribusi yang berbeda terhadap pengembangan kegiatan masyarakat kampung biru. Pengaruh jenis pekerjaan terhadap pengembangan kegiatan masyarakat di Kampung Biru Arema ini yang akan dikaji. Masyarakat kampung biru memiliki kegiatan masyarakat berupa karja bakti yang dilaksanakan selama sebulan sekali yang diikuti oleh seluruh warga.

Harmonisasi ini lah yang dimaksud dengan solidaritas mekanis yang terjalin dengan kesadaran berbasis moralitas antar individu serta individu dengan kelompok. Di Kampung Biru Arema ini juga demikian, adanya solidaritas mekanis di dalam struktur masyarakatnya menjadikan warga untuk saling mendorong dan mensupport satu sama lain.

\section{Daftar Rujukan}

Ritzer, George. \& Goodman, Douglas J. 2008. Teori Sosiologi (Edisi Terbaru). Bantul: Kreasi Wacana.

Sasongko, Darmadi. 2018. Kampung Biru, ikon baru Kota Malang sebagai Bhumi Arema. Merdeka.com. (Online) (https://www. merdeka.com/peristiwa/kampung-biru-ikon-barukota-malang-sebagai-bhumi-arema.html) . Diakses pada 10 Februari 2018.

Fizriyani, Wilda. 2017. Malang Siapkan Kampung Wisata Bernuansa Biru Arema. Republika.co.id.(Online)(http://nasional.republika.co.id/berita/nasional/daerah/17/10/ 30/oymtmw328-malang-siapkan-kampung-wisata-bernuansa-biru-arema). Diakses pada 10 Februari 2018.

Winarsih, Baendhowi, \& Bandi. 2014. Pengaruh Tenaga Kerja, Teknologi, dan Modal dalam Meningkatkan Produksi di Industri Pengolahan Garam Kabupaten Pati. Jurnal Pndidikan Islam Mandiri, (Online), Vol 3, (https://www.neliti.com/publications/13879/pengaruhtenaga-kerja-teknologi-dan-modal-dalam-meningkatkan-produksi-di-industri), diakses 12 Februari 2018.

Golu. W. 2002. Metode Penelitian. Upi Edu. (Online) (http://aresearch.upi.edu/operator/upload/s_mrl_055415_chapter3.pdf). Diakses pada 26 Februari 2018. 